\title{
RECYCLING OF MARBLE CALCITE WASTE INTO USEFUL ARTIFICIAL MARBLE
}

\author{
Nehal A. Erfan \\ Department of Chemical Engineering, Faculty of Engineering, Minia University, Minia 61111, Egypt \\ *Corresponding Author E-mail: n.erfan1@mu.edu.eg
}

\begin{abstract}
Artificial stone production by incorporating calcite marble waste in epoxy resin is a technical and economical method. A huge amount of waste is annually generated during marble processing in Egypt. This study aims at evaluating the mechanical and physical properties of produced artificial marble based on calcite marble waste as load, epoxy resin and lime powder as a filler. The results confirmed that the produced artificial stones have physical and mechanical properties within the expected range for these kinds of materials. Artificial marble with a maximum flexural strength of 21.79 $\mathrm{MPa}$, maximum compressive strength of $89.26 \mathrm{MPa}$, water absorption $0.01 \%$ and a satisfactory adhesion between load and resin were obtained. Using lime powder as a filler represents an enhancement in the produced artificial marble mechanical properties. Lime powder is very cheap in El-Minia region in Egypt and to the best of our knowledge has not been used for artificial marble production before. The materials produced can be used as an alternative material for civil construction applications.
\end{abstract}

Keywords: Artificial marble, Calcite marble, Compressive strength, Flexural strength, Water absorption.

\section{INTRODUCTION}

A significant increase in extraction of natural stones such as granite and marble is observed recently. Marble is composed of calcite crystallized by metamorphism ranges from granular to compact texture. The density of calcite marble is $2.7 \mathrm{~g} / \mathrm{cm} 3$ and it has a porosity of $0.4 \%$ (Carlos E. Gomes Ribeiro et. al., 2014) [1]. Every crystalline rock constitutes mainly of minerals with a Mohs hardness of 3-4,' is considered marble according to UNI 8458 standard. $70-75 \%$ of the whole extracted materials are lost as

Received:13 November, 2019, Accepted: 21 January, 2020 byproducts in marble production. The calcium carbonate obtained from waste marble pulverization can be used in many industrial applications.

In addition, a thinner powder can be used to for concrete production [2]. Some authors studied the effect of using stone residues on properties of concrete mortars and ceramic bricks $[3,4]$. Polyester artificial Stones show an excellent decorative effect. The artificial stone products have different designs, texture, color and patterns. The reason for that is the usage of different types of natural stones in 


\section{Vol. 40, No. 1. January 2021}

different granular sizes and qualities, different pigments and different processing techniques. Artificial stones have strong wear resistance and high strength. The folding strength of artificial marble is up to $25-40 \mathrm{MPa}$, the compressive strength reaches up to $80-100$ $\mathrm{MPa}$ and Brinell hardness up to $32-40 \mathrm{HB}$ which is a little lower than that of natural marble, so it has stronger wear resistance. Artificial stones are strongly resistant to alkalis, acids and stains, the reason for that is the usage of unsaturated polyester resin as bonding agent. The production techniques of artificial stones are very simple. Molding technique includes pouring, pressing and large block molding. According to design requirements, artificial marble can be made into different shapes, sizes, colors and glosses. Comparing to natural marble, artificial marble is more workable and easier for sawing, drilling and punching. The weak thermal resistance of polyester artificial stone (service temperature not higher than $200^{\circ} \mathrm{C}$ ) limits its uses to be indoors [5]. The slab surface may gradually lose its gloss or get quality problems such as darkening or warpage by exposure to light, heat or electricity in the air. In this study, artificial marble based on marble waste and epoxy resin was produced. In addition, this work represents the effect of adding lime powder as filler. Physical and mechanical properties of the produced artificial marble compared to natural marble were investigated.

\section{MATERIALS AND METHODS}

\subsection{Marble Residue}

The residue of "Calcite" natural marble (NM), from El-Minia, Egypt, was used in this study. Scraps of plates were collected in a discarding pile. After the material collection, the residue was crushed using a Hummer, so that particles could pass through a $3.15 \mathrm{~mm}$ sieve. Using dry sieving, the crushed residue was separated into three granulometric ranges.
The coarse particles used are in range 2-3.15 $\mathrm{mm}$, medium particles are in range $0.8-2 \mathrm{~mm}$, and the fine particles are less than $0.8 \mathrm{~mm}$.

\subsection{Unsaturated Polyester}

An orthophthalic unsaturated polyester (UPR) resin with a medium viscosity was used to formulate all composites. $1 \mathrm{wt} \%$ methyl ethyl ketone peroxide (MEKP) was used as an initiator.

\subsection{Calcium Carbonate}

Calcium carbonate, a widely available natural inorganic compound, also known as limestone, chalk or marble. In this study calcium carbonate powder from El-Minia quarries was used. Pure $\mathrm{CaCO}_{3}$ is an odorless, fine white powder. It has a density of 2.71 $\mathrm{g} / \mathrm{mL}$ molar mass of $100.1 \mathrm{~g} / \mathrm{mol}$ and melting point of $1,339^{\circ} \mathrm{C}$, as its calcite form.

\subsection{Sample preparation}

9 specimens were cast for mechanical and physical properties determination. Based on simplex mixture design, the waste marble particles percentage range was chosen (coarse particles range is $2-3.15 \mathrm{~mm}$, medium particles are in range $0.8-2 \mathrm{~mm}$, and the fine particles are less than $0.8 \mathrm{~mm}$ ). The crushed and classified particles were dried after water washing. Water reduces the adhesion between the composite components, because of that drying the particles is a necessary step. Calcium carbonate was added in (5-55 wt\%) range. Polyester resin was added in (23-29 wt $\%)$ range. For homogeneous paste, a 5 minutes mixing between marble particles, resin and lime powder was important. The paste was poured into the prepared molds $(50 * 50 * 50 \mathrm{~mm})$ for compression water absorption and density tests and $(40 * 45 * 120$ $\mathrm{mm}$ ) for flexural strength test. The mold was vibrated to spread the mass, and pressed. The pressed paste was left 24 hours for drying. 
Vol. 40, No. 1. January 2021

Table 1. Size analysis of Test specimens.

\begin{tabular}{|c|c|c|c|c|c|}
\hline Specimens & ${\text { Coarse } \boldsymbol{\%}^{\mathbf{a}}}^{\text {Medium }}$ & $\begin{array}{c}\text { Fine }^{\mathbf{a}} \\
\mathbf{\%}^{\mathbf{a}}\end{array}$ & UPR \% $^{\mathbf{b}}$ & Lime \% \\
\hline C1 & $\mathbf{2 0}$ & $\mathbf{5 0}$ & $\mathbf{3 0}$ & 28.57 & - \\
\hline C2 & $\mathbf{1 5}$ & $\mathbf{6 0}$ & $\mathbf{2 5}$ & 28.57 & - \\
\hline C3 & $\mathbf{1 0}$ & $\mathbf{7 0}$ & $\mathbf{2 0}$ & 28.57 & - \\
\hline P1 & 10 & 70 & 20 & 28.57 & $\mathbf{5 0}$ \\
\hline P2 & 10 & 70 & 20 & 28.57 & $\mathbf{5 5}$ \\
\hline P3 & 10 & 70 & 20 & 28.57 & $\mathbf{6 0}$ \\
\hline R1 & 10 & 70 & 20 & $\mathbf{2 3 . 0 7}$ & 50 \\
\hline R2 & 10 & 70 & 20 & $\mathbf{2 5 . 9 2}$ & 50 \\
\hline R3 & 10 & 70 & 20 & $\mathbf{2 8 . 5 7}$ & 50 \\
\hline
\end{tabular}

${ }^{\mathrm{a}}$ percentage by weight of marble load (Coarse+ medium + fine).

${ }^{b}$ percentage by weight of material (Marble load+ unsaturated polymer).

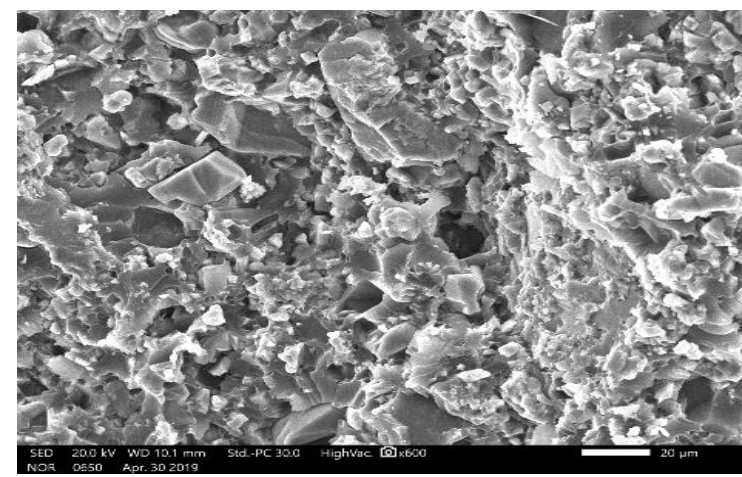

(a)

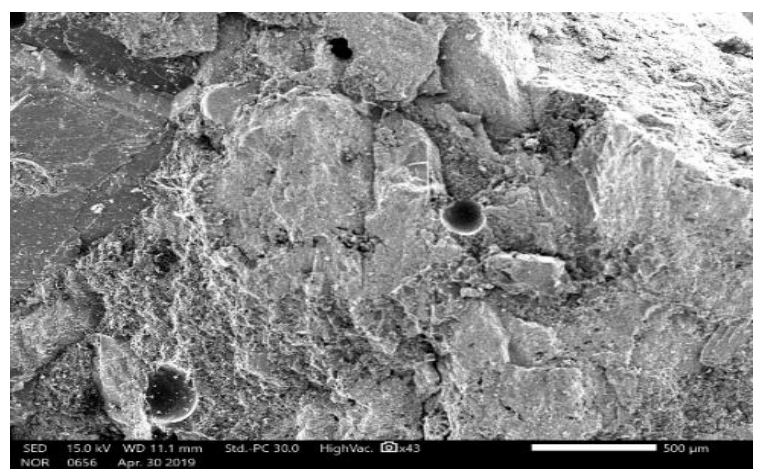

(b)

Fig.1. SEM micrograph of P3 sample a-600 X and b- $43 \mathrm{X}$ magnification.

\section{RESULTS AND DISCUSSION}

\section{1 morphology and microstructure}

Figure 1 represents the SEM micrographs of P3 sample. Mechanical stress and particles adhered to resin are the reason for the intergranular fractures with mechanical disruption present in artificial marble surface. This morphology explains the specimens/ingredients effective interfacial adhesion. In figure 1 heterogeneity and cavities are pronounced due to unsatisfactory adhesion between resin and load. Particles in contact without interface with resin may act as stress concentrators.

\subsection{Physical properties}

The water absorption value of the sample having the highest compression strength (P3) was found to be $0.01 \%$ (figure 5 ). This value is $45 \%$ below the minimum expected for the industrialized artificial marble. The values reported by artificial marble manufacturers are in the range from 0.09 to $0.40 \%$ according to Chiodi and Rodriguez [6]. An artificial marble with a water absorption value below $0.1 \%$ has a very high quality [6]. The typical range of water absorption for natural marble is (0.80.04)) [7].This low water absorption value is due to the efficient wetting of the load by the resin, giving a good interface for the produced material. The recorded water absorption value is also lower than recommended for calcite marble (material regulated by ASTM C503) which should have $0.2 \%$ water absorption value at least $[8,9]$. The density value of $\mathrm{P} 3$ specimen was found to be $2.008 \mathrm{gm} / \mathrm{cm} 3$. This value is compatible with the value obtained by lam dos santos et al., [10]. 


\subsection{Mechanical properties}

\subsubsection{Effect of particle size}

Figure 2 and Table 2 represents the effect of waste marble particle size on the compressive ultimate strength. The three composites $\mathrm{C} 1, \mathrm{C} 2$ and $\mathrm{C} 3$ are at least twice the natural marble ultimate strength and nearly half of the unsaturated polyester ultimate strength. A higher dispersion is presented by marble compared to the unsaturated polyester resin. Furthermore, the produced artificial marble specimens have lower dispersion compared to natural marble. The resin incorporation gives a more stable behavior to the produced composites.

Table 2. Effect of particle size on compressive ultimate strength.

\begin{tabular}{|l|l|}
\hline Specimen & $\begin{array}{l}\text { Ultimate compressive strength } \\
\text { (MPa) }\end{array}$ \\
\hline C1 & 67.03 \\
\hline C2 & 68.08 \\
\hline C3 & 70.77 \\
\hline NM & 29.3 \\
\hline UPR & 150 \\
\hline
\end{tabular}

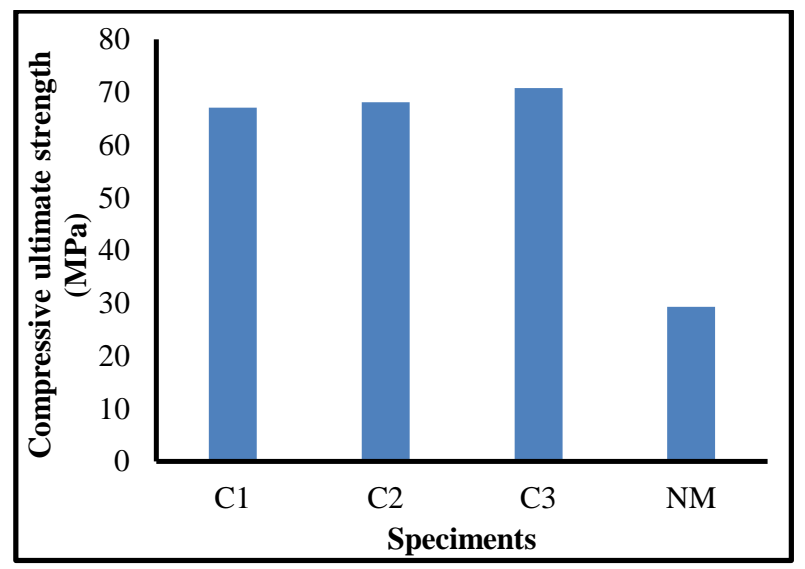

Fig.2. Effect of particle size on compressive ultimate strength.

\subsubsection{Effect of Lime addition}

As shown from Figure 3, the flexural ultimate strength for the produced composites is 5 times lower than the polyester resin resistance.

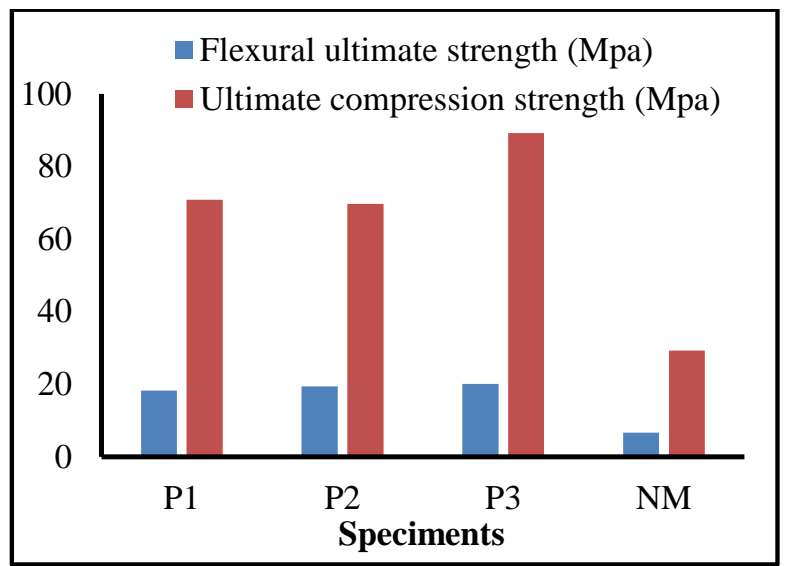

Fig.3. Effect of lime addition on compressive ultimate strength and flexural ultimate strength.

Table 3. Effect of lime addition on flexural ultimate strength and ultimate compression strength.

\begin{tabular}{|l|l|l|}
\hline Specimen & $\begin{array}{l}\text { Flexural } \\
\text { ultimate } \\
\text { strength } \\
(\mathrm{MPa})\end{array}$ & $\begin{array}{l}\text { Ultimate } \\
\text { compressive } \\
\text { strength } \\
(\mathrm{MPa})\end{array}$ \\
\hline $\mathrm{C} 1$ & 18.26 & 70.80 \\
\hline $\mathrm{C} 2$ & 19.4 & 69.70 \\
\hline $\mathrm{C} 3$ & 20.11 & 89.26 \\
\hline NM & 6.7 & 29.3 \\
\hline UPR & 95.3 & 150 \\
\hline
\end{tabular}

In addition, the ultimate compression strength is nearly half the polyester resin strength. Powdered fillers incorporation decreases the flexural strength and the compression strength of the polyester resin [11]. Compared to natural marble, the produced composites have three times greater flexural ultimate strength. Furthermore, increasing the lime content in the composite samples increased the compression ultimate strength to reach $89.26 \mathrm{MPa}$ at $60 \%$ Lime. This value is nearly five times greater than the natural marble resistance. In addition, comparing Figures 2 and 3, enhancement in compressive ultimate strength can be noticed by increasing the lime powder filler content. The obtained enhancement can be attributed to the reduction in the specimen's voids and porosity by adding the filler. Furthermore, the presence of the filler enhances the mechanical properties of the produced composites. This is 
because the filler reduces the movement of the molecular network and increases the molecular interconnection between the matrix and the load.

\subsubsection{Effect of resin content}

Figure 4 and Table 4 represent the effect of increasing resin content on the compressive strength of the produced artificial stone samples. The compressive strength of the three tested samples lying between their constituents, as expected for a mixture. Increasing resin percentage, results in a considerable increase in compressive strength. This can be due to the increase in the degree of molecular interconnections between the matrix and the load by increasing the resin content. Natural marble crystal planes mobility is easier at time of compressive strength effort due to its particle's imperfections. This phenomenon is reduced by artificial marble production.

Table 4. Effect of resin content on ultimate compression strength.

\begin{tabular}{|l|l|}
\hline Specimen & $\begin{array}{l}\text { Ultimate compressive strength } \\
(\mathrm{MPa})\end{array}$ \\
\hline C1 & 64.65 \\
\hline C2 & 74.64 \\
\hline C3 & 89.26 \\
\hline NM & 29.3 \\
\hline UPR & 150 \\
\hline
\end{tabular}

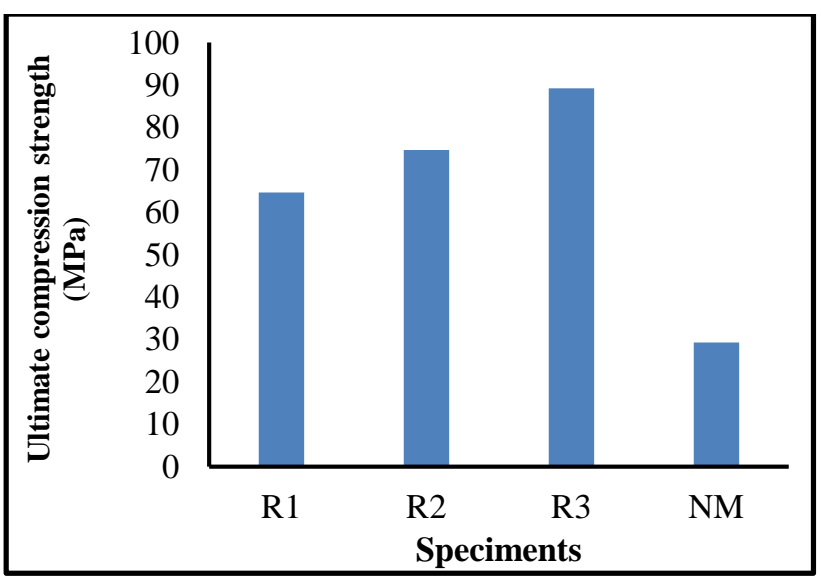

Fig.4. Effect of resin content on ultimate compression strength.

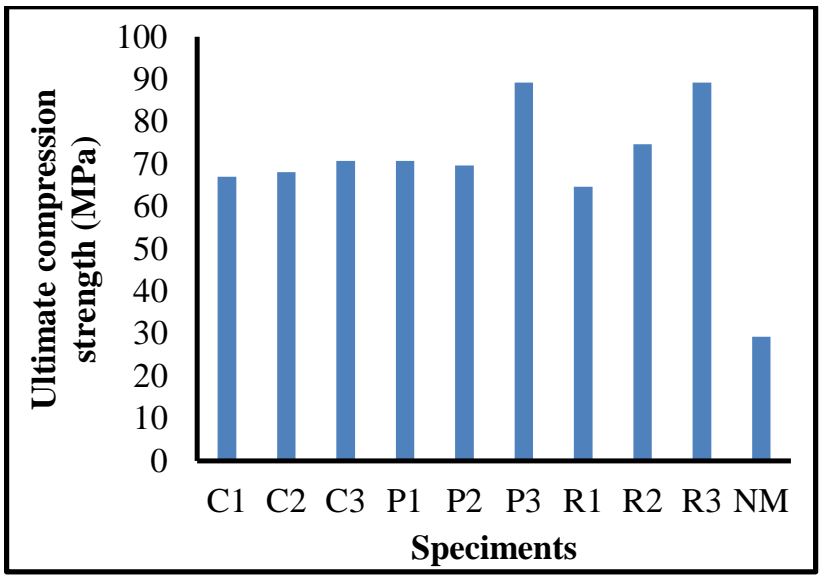

Fig.5. Comparison between the ultimate compression strength of all the samples.

\section{CONCLUSIONS}

In this study artificial marble slabs have been manufactured successfully. The produced specimens have maximum compressive strength of $89.26 \mathrm{MPa}$, Flexural ultimate strength of $21.79 \mathrm{MPa}$, water absorption of $0.01 \%$ and density of 2.008 $\mathrm{gm} / \mathrm{cm} 3$. Mechanical and physical tests confirm that the prepared samples properties lie within the expected specification standard range. Adding lime powder as a filler enhanced the mechanical properties of the produced artificial marble. Lime powder is very cheap in this region in Egypt and to the best of our knowledge has not been used before for artificial marble production.

\section{REFERENCES}

[1] Ribeiro, C.E., R.J. Rodriguez, and C.M. Vieira, Production of ornamental compound marble with marble waste and unsaturated polyester. in EPD Congress. (2014).

[2] H.F. Mothe Filho, H. Polivanov, E. V. Barroso, C.G. Mothe, thermal and mechanical study from granite and marble industry reject. Thermochimica Acta, 392(2002) 47-50.

[3] J.B.Silva, D. Hotza, A.M. Segadaes, W. Acchar, Incorporacao de lama de marmore e granite em massas argilosas, ceramica, 51(2005)325-330. 


\section{Vol. 40, No. 1. January 2021}

[4] W.A. Moura, M.B.Leite, Estudo da viabilidade de producao de blocos com utilizacao de residuo de serragem de rochas ornamentais para alvenaria de vedacao, REM. Revista Escola de Minas, 64(2011)147-154.

[5]. Building Decorative Materials. (2011) https://www.sciencedirect.com/science/book/ 9780857092571.

[6] Chiodi Filho, C. and R. EdeP, Guia de aplicação de rochas em revestimentos. São Paulo: Abirochas, 2009.

[7] Y.Ozcelik and A.Ozguven, Water absorption and drying features of different natural building stones. Construction and building materials, 63(214)257-270.

[8] Lee, M.-Y., et al., Artificial stone slab production using waste glass stone fragments and vacuum vibratory compaction. Cement and Concrete Composites, 30(2008)583-587.
[9] Borsellino, C., L. Calabrese, and G. Di Bella, Effects of powder concentration and type of resin on the performance of marble composite structures. Construction and Building Materials, 23(2009)1915-1921.

[10] dos Santos, J.L., L. Rosa, and P. Amaral, Temperature effects on mechanical behaviour of engineered stones. Construction and Building Materials, 25(2011)171-174.

[11] G. Gunduz, Processing of Unsaturated Polyesters. Advanced Polymer Processing

Operations, ed. N.P. Cheremisinoff, (Westwood, NJ: William Andrew Publishing, (1998) 1-38. 


\section{الاستفادة من مخلفات الرخام الطبيعي باعادة تدويرها للحصول علي رخام صناعي}

الملخص:

يمثل دمج نفايات رخام الكالسيت في راتتجات الايبوكسي لإنتاج الحجر الصناعي طريقة تقنية اقتصادية. يعد استخدام نفايات الرخام قابلاً للتطبيق من الناحية البيئية ، مما يقلل من كمية المخلفات المهملة في البيئة ، ويضيف قيمة اقتصادية إلى نفايات الرخام مما يتيح توليد فرص العمل. سجل إنتاج الحجر الطبيعي في مصر كمية هائلة من النفايات الناتجة عن معالجة الرخام. تهذف هذه الدراسة إلى تثييم الخواص الميكانيكية والفيزيائية للرخام الصناعي المنتج بناءً على نفايات رخام الكالسيت كحمولة وملء وراتتجات الايبوكسي. أوضحت النتائج أن الأحجار الصناعية المنتجة تظهر خواص فيزيائية وميكانيكية ضمن النطاق المتوقع لهذه الأنواع من المواد. تم الحصول على رخام صناعي ذو قوة انحناء قصوى تبلغ V9. I. ميجا باسكال ، وقوة ضغط قصوى تبلغ جץ.9 ميجا باسكال ، وامتصاص الماء ا ... ٪ والتصاق مُرض بين الحمل والراتتج. المواد المنتجة مع جزيئات رخامية بنسبة • v ٪ وراتتج راتتجات الايبوكسي ٪ و 0. ٪ كربونات الكالسيوم كمادة حشو تمكن من تطوير مادة بديلة لتطبيقات البناء المدني. 